より，裹波制御溶接が可能となった。

終りに，本研究を遂行するにあたって終始御激撅之適 切な指導を賜わった名古屋大学工学部，益本功教授に深 く感謝の意を表します。
引用 文 揇

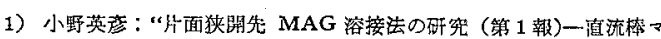

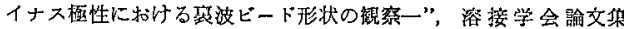
Vol. 3 (1985), No. 2

\title{
全姿勢プラズマキーホール溶接法の検討*
}

\author{
羽田光明**，今永炤慈**，荒谷 雄**，松本輝夫***
}

\section{Study on All-position Plasma Keyhole Welding*}

\author{
by Mitsuaki Haneda**, Shoji Imanaga**, Takeshi Araya** and Teruo Matsumoto***
}

In this study, a pulsed current plasma arc is applied to the keyhole operating mode to control solidification of the molten pool. Further, the pulse time, peak current, and plasma gas flow rate are especially investigated.

A one-pulse/one-keyhole range of pulse times by low frequency is obtained at each of four positions (Flat, Overhead, Vertical-up, and Vertical-down). As a result, suitable pulse times for some combinations of the plasma gas flow rate $(Q)$ and the peak current $\left(I_{p}\right)$ are the peak time $\left(t_{p}\right)=0.2-0.4 \mathrm{sec}$ and the background time $\left(t_{b}\right)=0.4-0.6 \mathrm{sec}$ at welding speed $(v)$ of $120 \mathrm{~mm} / \mathrm{min}$ in case of stainless steel pipe (JIS SUS304, $4 \mathrm{~mm}$ thickness).

Then fixed pipes are welded, and it is found that orbital welding is possible by starting from the 4:30 position and by control of the plasma gas flow rate, the peak current, and the welding speed according to the welding position at $6: 00$ or 7:30, 9:00, and 12:00 (o'clock) positions.

And effect of joint alignment error is studied, and it is found that permitted limits with cap pass weld. ing are miss-matching $=1.0 \mathrm{~mm}$, root-gas $=0.5 \mathrm{~mm}$, arc-length $= \pm 1.0 \mathrm{~mm}$, and arc-deviation $=1.0 \mathrm{~mm}$ in case of mild steel pipe (JIS STPG38, $4 \mathrm{~mm}$ thickness).

Key Words: Plasma arc welding, Plasma keyhole welding, All-position welding, Orbital welding, Pipe welding, Pulsed current welding

\section{1. 緒}

プラズマキーホール溶接は I 形突合せ継手で安定した 夏波が得られる片面溶接法として活用されているが，そ の適用姿勢は主として下向き姿勢に限定されている。プ ラズマキーホール溶接法による全姿势溶接の検討は10数 年前に始まり，溶融池の保持に関する基礎研究》が行わ れたが，当時は一定電流で檢討されたため適正ビードの 得られる溶接条件範囲が極めて狭く，最近まで実用に供 された報告がなかった。

しかし，近年，TIG 溶接と同㥞にプラズマキーホー 儿溶接で香，条件域の搪大や安定化を目的とした溶接電 流制御の検討が行われており，パルス電流の応用に関す る $2 \sim 3$ の研究が報告されている ${ }^{2,3)}$. また，昭和56年の 溶接協会訪中記によると，固定管の自動パルスプラズマ 溶接が実施されていることが分かる4).

そこで, 本研究では溶融池の溶瀜・半凝固現象を制御 する目的で，低周波パルス電流を利用した場 合のキー ホール形成現象に注目し，全姿勢溶接条件を検討すると

\footnotetext{
*原稿受付 昭和 60 年 4 月17日 昭和 59 年度春季全国大会で発琵 昭和58年11月溶接アーク物理研究委員会で発表

**正員 (株)日立製作所機使研究所 Member, Mechanical Engineering Research Laboratory, Hitachi, Ltd.

***正員 (株)日立製作所ンフトゥエフ工昜 Member, Software Works, Hitachi, Ltd.
}

と香に固定管の全周溶接に適用したよきの溶接結果につ いて教察した。

\section{2. 実験方法及び装置}

Fig. 1 亿示す実験装置により，基礎的現象及ひ溶接条 件を検討した。試験片は，最初化軟鋁上りキーホール溶 接が容易であるステンレス鋼管（材質 SUS 304），を用 いて，肉厚を TIG 溶接の場合のI 形突合せ継手の実用 溶接限界の $4 \mathrm{~mm}$ とし，加熱の影響が少ない大径管 (外 径 $216.3 \mathrm{~mm}$ ) で検討した。先ず，プラズマトーチを固 定しパイプを回転して，下向き $[\mathrm{F}]$ ，上向き $[\mathrm{OH}]$ ，立 向き上進 $\left[\mathrm{V}_{u}\right]$, 立向き下准 $[\mathrm{Vd}]$ での溶接条件を bead-on-plate 溶接で求め, 次いで固定管の全周溶接の条 件制御を検討した。同様の手法で，軟鋼管（村質 STPG -38 , 肉厚 $4 \mathrm{~mm}$, 外径 $59 \mathrm{~mm}$. に内外周を機械加工) に ついても溶接条件を決定した。

溶接電源はサイリスタ制御方式の直流定電流特性を， Fig. 2(1) の模式図に示す矩形波パルスの電流值 $I_{p}, I_{b}$ 及びパルス時間 $t_{p}, t_{b}$ が任意江設定できるようにした が，電流波形記録(2)が示すように立上がりに過剩電流を 含む出力波形となった。 また，溶接中に $20 \mathrm{~A}$ の非移行 式のパイロットアークを常時併用して，低電流時のプラ ズマアークの安定化を図っているが，てれは同時に母材 への投入入熱の一部としてあ作用している.

プラズマガスは Arを使用し,シールドガスはサーマ 
ルピンチ効果によりアークが絞られる $\mathrm{Ar}+7 \% \mathrm{H}_{2}$ 混合 ガスを使用した．全周溶接の場合は, パイプ内面のバッ クシールドガスとして Ar を使用したが, 各姿势での検

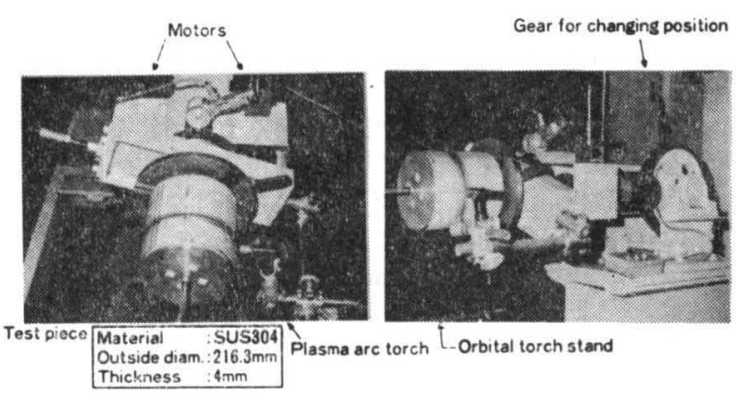

Fig. 1 Experimental Equipment

Current

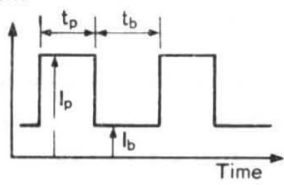

$I_{p}, t_{p}:$ Peak current, time $\mathrm{I}_{\mathrm{b}}, \mathrm{t}_{\mathrm{b}}:$ Background current, time

(1) Ideal wave

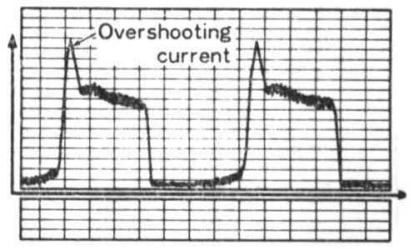

$\mathrm{I}_{\mathrm{p}, \mathrm{t}}: 100 \mathrm{~A}, 0.3 \mathrm{~s}$ $\mathrm{I}_{\mathrm{b}}, \mathrm{t}_{\mathrm{b}}: 35 \mathrm{~A}, 0.4 \mathrm{~s}$

(2) Practical wave
Fig. 2 Wave of Output Current
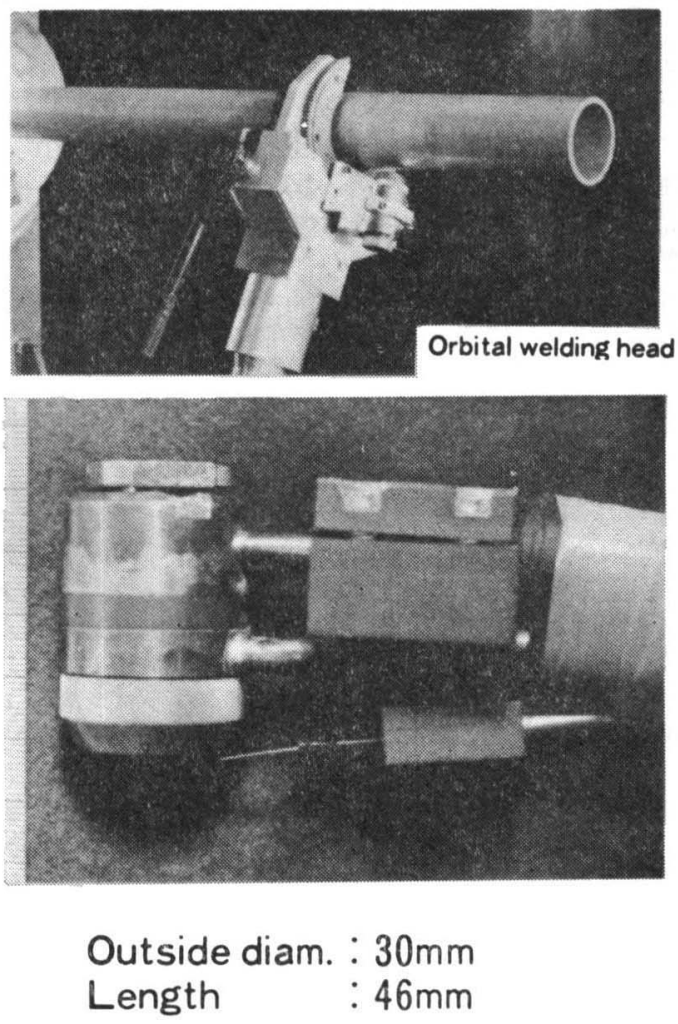

Fig. 3 All-position Orbital Welding Equipment
討はキーホールの観察に主眼を置きバックシールドをし ない状態で溶接したので，ビード外観などの評価は加味 していない。

Fig. 3 は小径管の全周溶接に使用した実験装置 の, 回転へッド及び小形プラズマトーチの外観で ある. また，Fig. 4 の構成図の中に定義した目違 い〔 $m]$, ギャップ[ $[g]$, アーク長 $[l]$, ねらいずれ 〔d 〕 の各誤差を設けた継手試験片により, 開先精 度, 組立て誤差の影響を検討した. これらの小径 管の実験には，トランジスタアナログ制御方式の 溶接電源を使用して, Fig. 2(1) の理想的な矩形波 パルス電流で溶接した。

\section{3. 実験結果及び考察}

\section{1 キーホール形成現象}

Fig. 5 は溶接諸条件とキーホール形成状態との 関係を, パルス時間 $t_{p}$ と $t_{b}$ で表わした図であ る. パルス電流值 $I_{p}, I_{b}$ 及びプラズマガス流量 Qを固定したとき，とのように図示すると平均電 流が等しい条件 ・パルス周期の等しい条件は, 図 中の各直線上に表示される. 溶接速度 $v$ が与えら れたときに, パルスどとのキーホールスポットの 重なり条件を決めると，連続した裏波が形成する 条件範囲が三角形として求められる。

今, ※印で表示したように $t_{b}$ のみを変化させた 場合は, Fig. 6 の式(1)で表わした入熱 $(v, Q$ の值 やキーホールの開閉に伴なう熱勃率の変化が影響

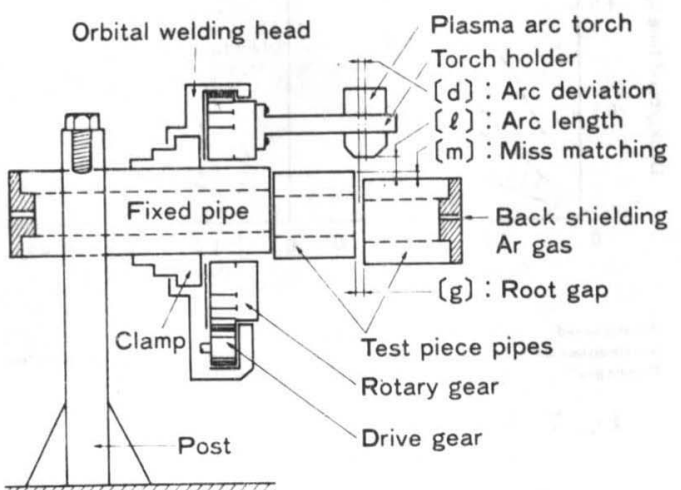

Fig. 4 Schematic Diagram of Orbital Welding Head for the Study of Joint Alignment Error

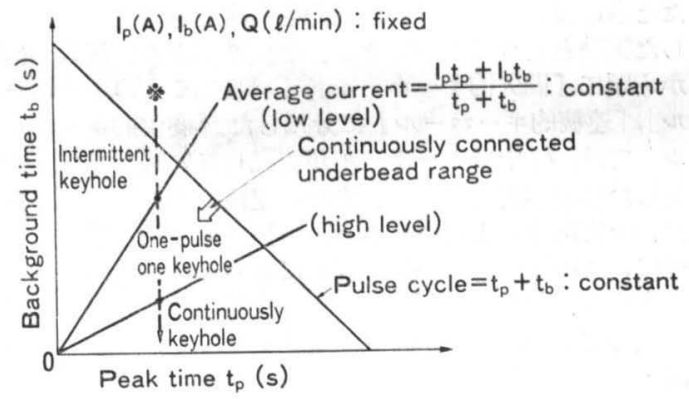

Fig. 5 Relation between Pulse Condition and Keyhole Formation 
Line $※ I_{p}, I_{b}, t_{p}:$ fixed

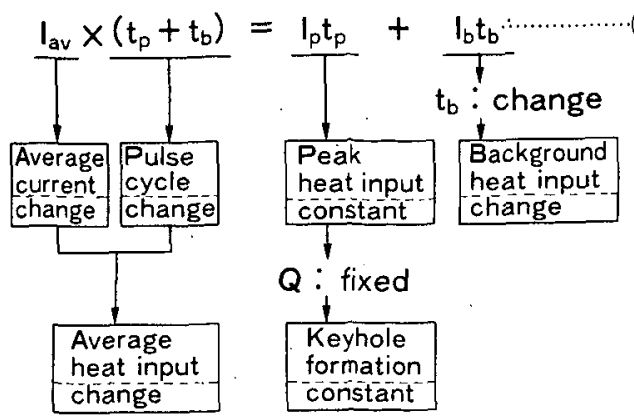

Fig. 6 Relation between Heat Input and Arc Force
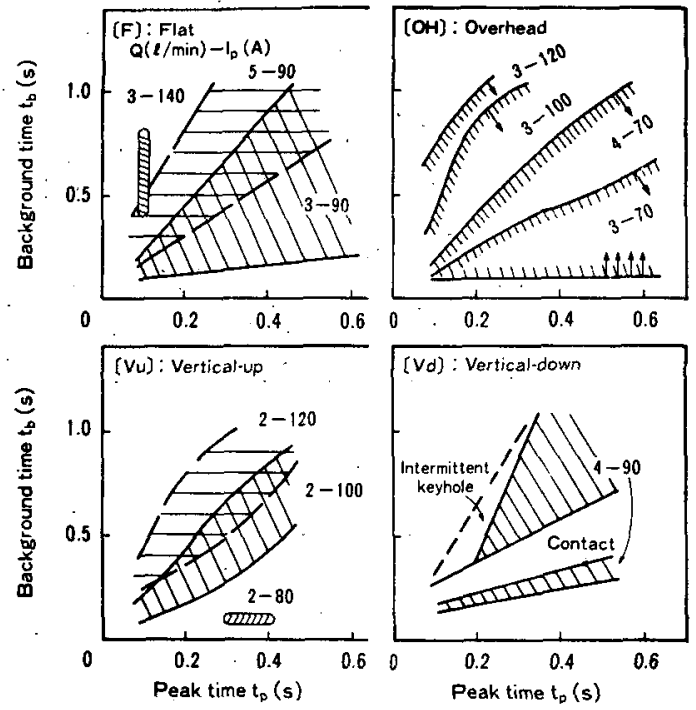

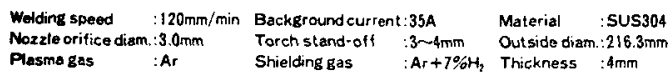

Fig. 7 Suitable Range of Pulse Times (One-Pulse/One-Keyhhole Condition)

するが; とてでは，電流入時間で表示)の $I_{p} \cdot t_{p}$ が一定 となる: 一方,アーク压力は電流の 2 乗に比例し5，※ 印の条件上では $I_{p}, t_{p}$ とも一定であるので $Q$ を固定し たときには，キーホール形成力を一定として入热を変化 した実験と言うことができる。溶接結果より，低入熱側 から順に「間欠的キーホール」,「パルスごとのキーホー ル」,「連続的キーホール」に分類した. 「間久的キーホー ル」では，I $I_{p}$ 中にキーホールが開孔しない時があり，連 続した裹波が得られない，また「連続的キーホール」で は,一定電流によるキーホール溶接で見られる現象上同 様に，[OH]及び $\left[\mathrm{V}_{u}\right]$ 姿勢において裹波のへてみが 発生する.「パルスどとのキーホール」では, $I_{p}$ と $I_{b} に$ 同期してキーホールが開孔・閉止するので, 溶融池の溶 融・半凝固によるビードの安定化が促進されて良好なビ 一ドが得られる. 以下，乙の適正条件範囲を One-pulse one-keyhole 領域之呼等.
Fig. 7 は Q-I .を固定し Fig. 5 の方式により. $t_{p}-t_{b}$ の 組合せを変えたときに，各姿勢にトーチを固定しパイプ の方を回転して One-pulse one-keyhole 領域を求めた 結果である. 各姿勢で $Q-I_{p}$ の条件定制御することを前

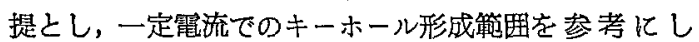

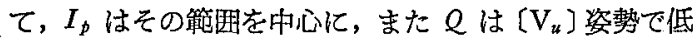
く, $\left[\mathrm{V}_{d}\right]$ 姿势で高く設定したいくつかの組合せを検討 した。ここでは紙面の都合で，適正範囲の広い代表的な 条件及び特徵的な現象が観察される条件を記述した。ま た， $I_{p}$ が $180 \mathrm{~A}$ 程度まではダブルアークが発生しないよ うに, ノズル孔径を $3 \mathrm{~mm}$ とした。 とのノズル孔徍で は, 約 2 3 $\mathrm{mm}$ のキーホールが形成さ机るので, $1 \mathrm{~Hz}$ 程度のパルス周波数で50\% 程度の重なり代の連続した裹 波が得られる。として $120 \mathrm{~mm} / \mathrm{min}$ を採用した。 な お, $v$ は入熱及びアーク直下への浴融金属の挙動に関係 する因子であり，溶融池形状が变化して，キーホール形 成の難易に影響を与える。また， $I_{b}$ は最低設定值の 35 Aにした。

この結果より，各姿勢とも Fig. 5 で述べた等入熱の条 件を示す 2 本の直線で团まれた範囲に, One-pulse onekeyhole 領域吕存在するととが分かる。ささらに，[F]资 勢で入熱が過多で，キーホール形成力が大きい条件で

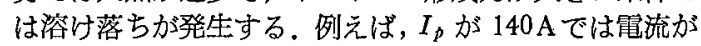
過大であるため，極めて短い $t_{b}=0.1 \mathrm{~S}$ においてわずか 亿適正籁用少存在し，それ以上の $t_{p}$ では連続的キ一 ホールあるいは溶け落ちとなる。[OH]资勢では溶融金 属がキーホールをるさぐ作用をしてアーク圧力で溶瀜池 が支えられるため，大入熱側にも適正螌囲が拡大され る. $\left[\mathrm{V}_{u}\right]$ 姿勢では溶融金属がアーク (ノズル孔) 直下 から直ぐに垂れ落ちるため，プラズマガスによるキー ホール形成力は弱い方が良い，そして，アンダーカット のない平滑な表ビードを得るには，溶融池幅が広く形成 されるワインカップ状の溶込み形状が必要であり，一定 電流では切断になるような高電流のI $I_{p}$ にする方が適正 範囲が搪大する，例えば， $I_{p}$ が一定電流でのキーホー ル形成条件である $80 \mathrm{~A}$ では， $t_{b}=0.1 \mathrm{~S}$ のほとんど一定 電流江近い条件で適正範囲が存在するが， $t_{p}$ は $0.3 \sim$ $0.4 \mathrm{~S}$ と極めて狭い。これが, 高電流の $I_{p}$ にして図示の ように搪大する。 $\left[\mathrm{V}_{u}\right]$ 姿勢では溶融金属がレズル孔直 下に垂れ下がってキーホールを閉じるため，大きなキ一 ホール形成力を必要とするが，I $I_{p}$ を高電流にするとか えって溶融池が大きくなるので，Qを高流量认設定する 方が良い，しかし，キーホールが形成してあアーク圧力 の変動で溶融池が欦き上げられ，溶融金属と卜ーチの， ズル先端が接触する領域が存在する。本実験ではノズル とパイプ表面との距髉（アーク長 $l$ ) $3 \mathrm{~mm}$ 没設し ているので, TIG 溶接あるいはパルスプラズマ溶接で 検討されている溶融池の共振周波数 $(20 \mathrm{~Hz} \text { 付近 })^{2,6)}$ 之 は異なり，キーホールの開閉に伴なう振幅の大きな振動 が原因で，周波数はパルス周波数そのあのである。ま た， $t_{b}$ が短くて溶蠤池が大きく成長する大入熱のパルス 条件域で接触か溌生しないてとから，この接触現象は溶 融池の大きさと，圧力変動，パルス周波数などの条件が 合致したときに発生すると推察できる。また， $I_{p}$ の立 ち上がりに発生する生力変動の大きさは，オーバーシュ 一トを含む電流波形倸負うところが大きい，後半に使用 したトランジスタ制御電源では，理想的な正形波となっ 
ているため压力変動が小さくなり，接触の影㗽が少な w.

\section{2 全姿势溶接条件}

パルス時間を各姿勢で制御することは技術的に容易で あるが, 各姿勢ごとにパルス時間 $t_{p}-t_{b}$ を変えずに全姿 勢溶接をするための適正範囲を求めた。

Fig. 8 の斜線部は, 前図の結果をむとにした One-puIse one-keyhole の領域の共通範团である。 $Q$ と $I_{p}$ は溶 接結果より各姿勢の適正值を選定した。また，溶接速度 が $120 \mathrm{~mm} / \mathrm{min}$ では, 前述のように $1 \mathrm{~Hz}$ 以上のパルス 周波数の之きに，50\%以上の重なり代で連続的につなが った裹波が形成した：との結果より，各姿势に共通した パルス時間条件は， $t_{p}=0.2 \sim 0.4 \mathrm{~S}, t_{b}=0.4 \sim 0.6 \mathrm{~S}$ の 簡囲にあるととが分かる。

Fig. 9 はパルス時閪を $t_{p}=0.3 \mathrm{~S}, t_{b}=0.6 \mathrm{~S}$ に固定 し，Qと $I_{D}$ を変えたときの One-pulse one-keyhole 領域である。[F]姿謷と比較して，[OH] 姿熬では $Q$

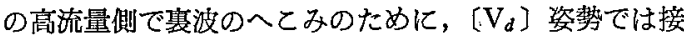
触現象のために適正範囲が減少し，[V $\left.\mathrm{V}_{u}\right]$ 姿势では Qに 対する条件裕度加狭い，固定管の全周溶接の場合，全周 にわたり一様なビード形状を得るには，入熱やアーク特 生がー定の状態で各姿勢を溶接することが望ましい，乙 こでは， $I_{p}$ を固定してもQを各姿勢で制御すれば全姿 勢溶接が可能であり，各资勢で溶融池形状，熱効率の違 いがあるが，入熱がほぼ一定の状態での全周溶接が可能 であることを示している。

\section{3 周定管の全周溶接条件}

固定管の全周浴接では溶接開始点が再び䅂了点となる ため，その位置 (姿势) と処理条件が重要である．プラ

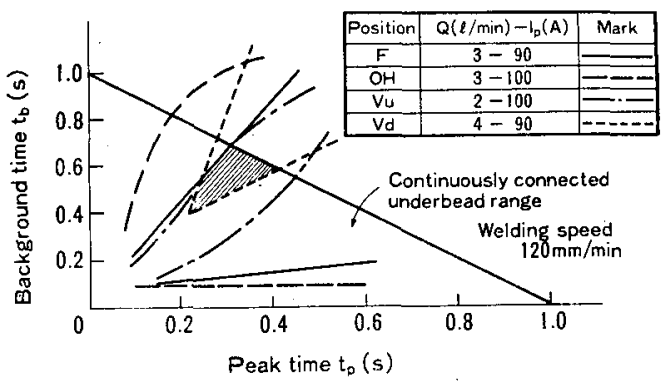

Fig. 8 Common Area of Suitable Pulse Times

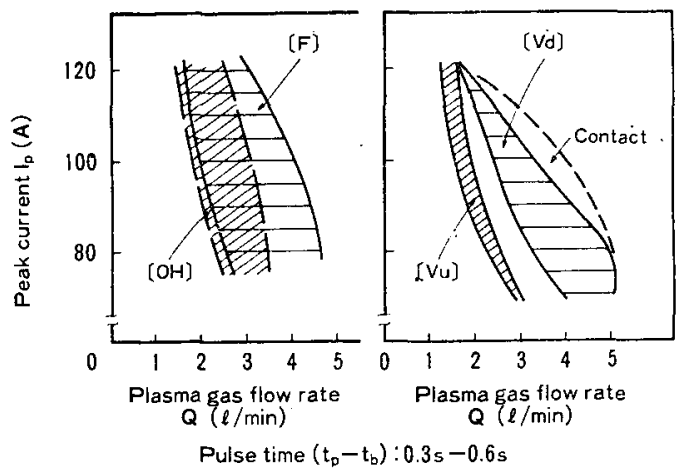

Fig. 9 Tolerance in Plasma Gas Flow Rate and Peak Current
ズマキーホール溶接では溶融池を貫通した穴が形成され ているため，溶接䅂了時にその穴を閉じる操作（クレー 夕処理) が必要である，徉来は [F] 姿势でクレータ処 理法が検討されているが，重力が溶骶池を押し下げるの で過熱状態になれば溶け落ちや凝固後のへとみが発生す る。また，小径管 (径 $100 \mathrm{~mm}$ 程度以下)では, 後半部 が予熱のために過熱するので, 溶接電流を低下するなよ゙ の条件制御をする必要がある，一方，固定管の全周溶接 では必ずしもクレータ処理を〔F]资勢で行う必要がな いので，溶融金属が垂れ下がってキーホールが閉じやす く，溶り落ちの発生し難い溶接姿勢を浴接終了点すなわ ち開始点とすることができる。ここでは時計表示で 4 時 半位置のトーチ姿勢を溶接開始点とした（溶接は時計回 りに進行).

次に，溶接条件切替位置についての検討結果を述べ る. Fig. 9 の結果に基づき，パルス時間を各姿勢とも共 通とし，かつできるだけ $I_{p}$ も固定条件で主しして Qを 制御することを前提に，各姿繁の溶接条件を選択した。 そして，Fig. 10(1) のようにパイプ全周を 4 分割する位 置に適用した結果から，次の現象が明らかになった。

$[\mathrm{OH}]$ 及び $\left[\mathrm{V}_{u}\right]$ 姿势では裹波加凹状になり易い．小 径管では 6 時位膡がアンダーカットの発生起点となる。

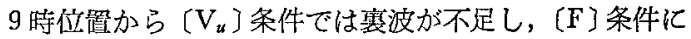
移る10時半位置で，Qの急增により寒波が過多となり， 12時位置加ら[F]条件では寒波が不足する。

これらの発生原因は，母材がパイプで曲率があるた め, 溶融池に作用する重力の方向を半径方向亡接線方向 に分けて考えた場合に，3，6，9，12時の各位置で作 用方向が反対方向に急変するためである，例えば6時の 位置では, 半径方向の分力は常にパイプ表面から外側に 姫いているが，接線方向の分力は 6 時を 0 として, 溶融 金属がノズル孔直下へ向う方向からノズル孔直下より後 退する方向へと急変するととが分かる。乙れが原因で， トーチの進行に伴ない溶融池の追従加亜々なり，6時以 降のアンダーカットの発生起点となる. 同様に，9時位 置では半径方向の分力が 9 時を 0 として，パイプ表面か ら外側へ働いていた分力がパイプの中心へ向う方向へと 変化するため，9時以降は溶融金屈がキ一ホールを埋め る方向に作用しキーホール形成力が不足する.また，12 時位置では接線方向の分力が，溶融金属がノズル孔直下 より後退する方向からノズル孔直下へ向う方向へと変化 して，溶融池が垂れ下がる方向に作用するため，12時以 降で裏波不足となる。

以上のように，トーチを固定し，パイプを母材として 回転させて求めた溶接条件の有効範囲は，Fig. 10(2) の

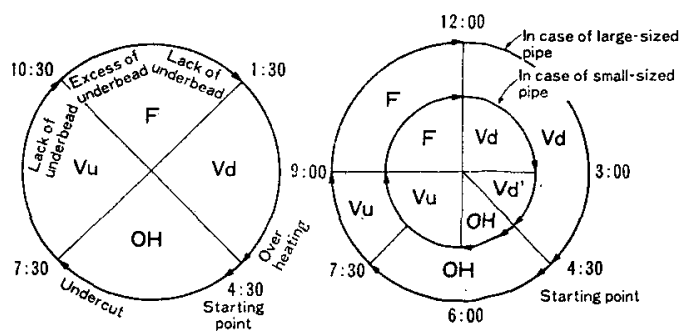

(1) Before correction

(2) After correction

Fig. 10 Position of Changing the Welding Conditions 
ように $45^{\circ}$ ずれる (1 時間半早く切替る) ことが分かっ た.さらに, 曲率の影響が小さい大径管では, 6 時以降 のアンダーカットの発生がないので $[\mathrm{OH}]$ 条件で溶接 可能である. また, 9 時位置で $[F]$ 条件にして Qを増 加すると, 裏波のへとみが防止でき， 3 時以降の溶接条 件は $\left[\mathrm{V}_{d}\right]$ 条件を採用して, 予熱の影響の大きい小径管 では $I_{p}$ を減少する制御動作で溶接可能であるととが分 かった。

Fig. 11 はステンレス鋼大径管のビード断面で, Fig. 10 の結果に基づき $I_{p}$ を一定とし, $Q$ を各位置で切替えて 溶接した. $\left[\mathrm{V}_{d}\right]$ 条件の後半では $v$ を速くして入熱を減 少するととあに，ノズル孔直下への溶融金属の垂れ下が りから逃れてキーホールが形成しやすくした．各姿势に おけるビード幅, 溶け込み形状はほぼ一椂で, パルスに 同期したリップルが形成される.

Fig. 12 は軟鋼小径管の溶接結果である. 溶接条件は

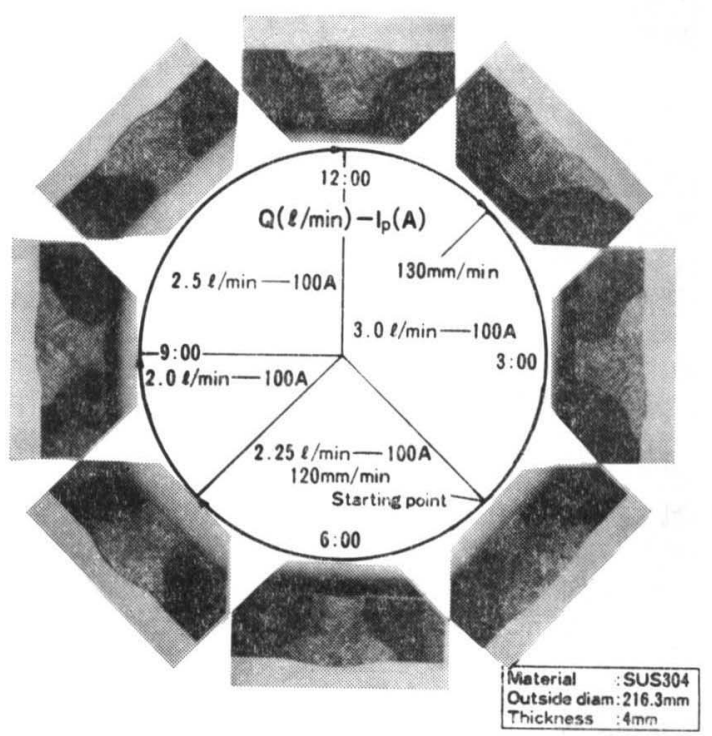

Fig. 11 Cross Sections of Stainless Steel Pipe Joint

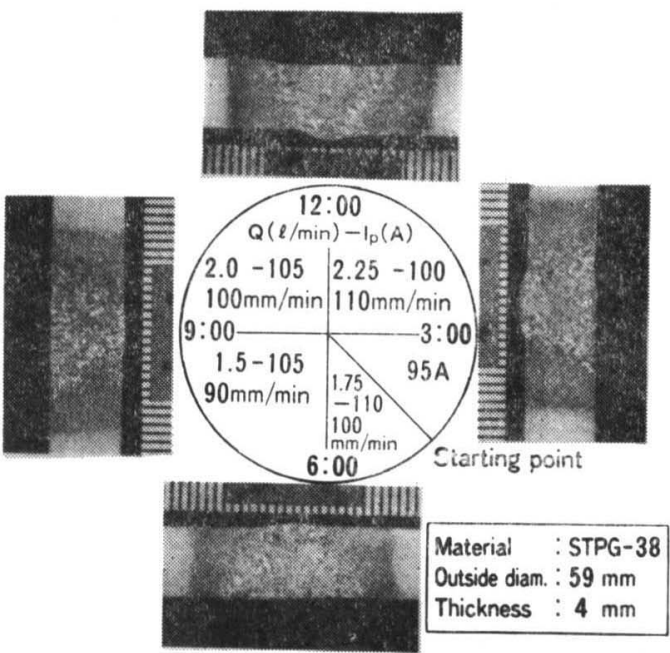

Fig. 12 Cross Sections of Mild Steel Pipe Joint
ステンレス鋼の場合と同樣の手法で求めたが, 主な相違 点はビード形成状態を考慮して，ノズル孔径を $2.4 \mathrm{~mm}$, 標準の $v$ を $100 \mathrm{~mm} / \mathrm{min}$ とした点である.さらに, $\left[\mathrm{V}_{u}\right]$ 条件では $v$ を遅くしてビード幅を広くするととあ に, 溶融池がトーチ進行に追従しやすくして, アンダー カットを抑制した。 また, $\left[\mathrm{V}_{d}\right]$ 条件の後半では $I_{p}$ を低 下して過熱を防止した。

\section{4 開先精度・組立て誤差の影響}

通常, TIG 溶接による固定管の全周溶接では, ルート ギャップを設定した精度の良いV 開先を用いて, 熱云導 による溶融現象で裏波を形成する。一方, プラズマキー ホール溶接では, I 形突合せ・ギャップ $=0$ が基本であ り，母材を貫通したアークで継手のルート部を直接溶融 して裏波を形成するため, 開先精度, 組立て誤差, アー ク変動の影響が少ない. しかし, ギャップに対しては キーホールの形成状態が大きく影響を受けると考えられ るが, パルス電流を応用した本溶接法では溶融池の安定 化が促進すると考えられる. そこで, とれらの許容値に ついて検討した.

Fig. 13 は $[m]=1.0 \mathrm{~mm},[g]=0.65 \mathrm{~mm}$ の継手を溶 接した一例で，目違いを設けた右側のパイプは〔l〕屯 $\pm 1 \mathrm{~mm}$ 変動する誤差が複合されている。こてでは, 初 首の裏波に注目し， 2 層目は溶加材を送給して仕上げ溶 接をする場合の各許容值を表示した。 $[m],[l],[d]$ は $1 \mathrm{~mm}$ 程度までの誤差であ裹波が平滑であり, 裕度が狭 いと考えられた $₫ \mathrm{~g}$ 〕についてあ, $0.5 \mathrm{~mm}$ 程度までは $[g]=0$ 之同一条件で全周溶接が可能である.

\section{4. 結 論}

プラズスキーホール溶接に低周波パルス電流を応用し 全姿勢溶接の検討を行い次の結論を得た。

(1) One-pulse one-keyhole 形成現象偖着目して適正 パルス条件を把握し，プラズマキーホール溶接の全姿勢 化の可能性を明らかにした。

（2）固定管の全周溶接におりる溶接条件切替制御法を 検討し，ステンレス鋼管及び軟鋼管に適用して平滑な枣 波で良好な溶け込み形状のビードを得た。
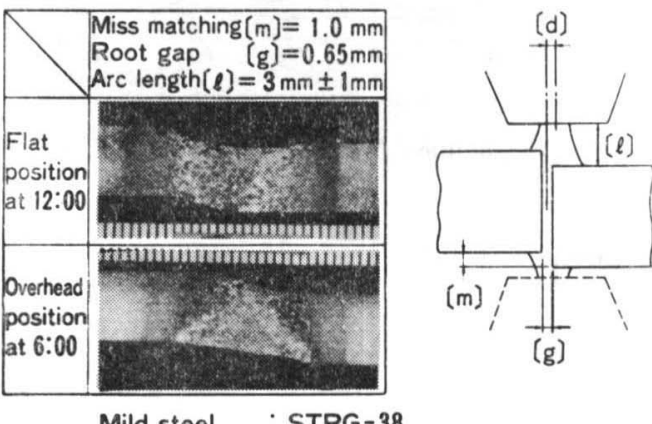

(g)

Mild steel : STPG-38

Outside diam. : $59 \mathrm{~mm}$, Thickness : $4 \mathrm{~mm}$

\begin{tabular}{|c|c|}
\hline Joint alignment error & Permitted limit \\
\hline Miss matching (m) & $0 \sim 1.0 \mathrm{~mm}$ \\
\hline Root gap & $0 \sim 0.5 \mathrm{~mm}$ \\
\hline Arc length & $3 \mathrm{~mm} \pm 1.0 \mathrm{~mm}$ \\
\hline Arc deviation (d) & $0 \sim 1.0 \mathrm{~mm}$ \\
\hline
\end{tabular}

I-butt keyhole + Cap pass welding

Fig. 13 Effect of Joint Alignment Error 
（3）開先精度，組立て誤差の影響について検討し，そ の許容値を提示した。

\section{参 考 文 献}

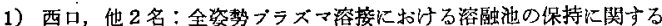
基喽的検討, 溶接アーク物理研究委員会資料，72-167 (1972)

2）丸尾，他 1名：バルスプラズマ溶接現象，溶接フーク物理研究委員 会資料， 85-579 (1985).
3) C. D. Lundin, 他 1 名: Pulsed Current Plasma Arc Welding, Welding J., 54-1 (1974), 11-19.

4) 新：日本溶接協会特殊材料溶接研究委員会勒中范，溶接技衡，298 (1981), 84-93.

5）岡田，他 2 同：TIG パルスフークのフーク匠力測定，溶接アーク 物理研究委員会資料， 78-382（1978）。

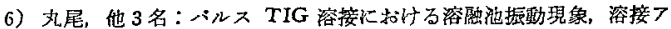
一ク物理研究委夏会盗料, $82-485$ (1982).

\title{
鋼管の磁気駆動アーク溶接におけるアーク回転現象*
}

高木健治**，荒木田史穂**，宮森英明**，小澤幹男***

\author{
Arc Rotating Phenomena in Rotating Arc Butt Welding of Steel Pipes*
}

by Kenji Takagi**, Fumiho Arakida**, Hideaki Miyamori** and Mikio Ozawa***

Arc behavior of Rotating Arc Butt Welding were studied in order to extend the applicable pipe diameter and thickness ranges. Experiments were carried out for $216.3 \mathrm{~mm}$ O.D $\times 5.8 \mathrm{~mm}$ wall steel pipes by using design of experiment in which gap, arc current and exciting current were selected as important experimental factors. Main resulis are summarized as follows;

(1) Arc rotating frequency is mainly affected by gap of pipes and arc rotating smoothness at the early stage of welding is affected by exciting current.

(2) The period of melting process and arc rotating process is influenced by arc current.

(3) Characteristic phenomena are observed by high speed photograph, such as showerlike spatter, small grain spatter, plural arc and dripping molten metal.

(4) It was observed much small grain spatters were dispersed at the small gap than large gap of pipes. The good quality of welded joint was not obtained at small gap condition.

Key Words: Rotating Arc Butt Welding, Steel Pipe, Magnetic Field, Exciting Coil, Showerlike Spatter, Small Grain Spatter, Arc Rotating Frequency

\section{1. 緒言}

溶接の自動化が推し進められている中で, パイプ溶接 に関しても TIG 法や MAG 法を中心として自動化の研 究開発が盛んに行なわれている。磁気駆動了ーク溶接法 は，2本のパイプ間ギャップにアークを発生させ，それ に直交する磁場との相互作用により円周方向に高速で回 転させ，その後圧接する方法である. TIG 法, MAG 法 とは異り，トーチの位置やその動きを制御する機構が不 要という簡単なシステムのため, 自動化に適している. 溶接されるパイプ自身が電極となり高電流の使用が可能 で非常に高能率であり，自動化，省力化に対するメリッ 卜は極めて大きい。

本溶接法はこれまでに管径 $50 \mathrm{~mm} \phi$ 程度の自動車用 部品 ${ }^{1)}$ や管径 $90 \mathrm{~mm} \phi$ までのガス導管の溶接に寒用化 ${ }^{22}$ されているが, 更に適用管径, 管厚を掋大するため溶接 現象の解明実験を行った。

本研究では, 磁気駆䧿アーク溶接法のアークの挙動に 及ぽす要因として，ギャップ，溶接電流及び励磁電流の 3 因子を選定し，てれらの因子のアーク挙動への影響に ついて検討した。

\footnotetext{
*原稿受付 昭和59年 7 月 4 日 昭和56年度秋季全国大会で発表

**正 貝 日本銅管工承(株) Meuber, Nippon Kokan Koji K. K.

***正 員 日本銅管工事(侏) Nippon Kokan Koji K. K.
}

\section{2. 実 験 方 法}

\section{1 供試鋼管及び実験装置}

実験使用した鋼管は配管用炭菜鋼鋼管 (SGP)，外径 $216.3 \mathrm{~mm} \phi$ ，管厚 $5.8 \mathrm{~mm}$ である.

実験装置の概要を Fig. 1 亿示す. 溶接用電源として直 流垂下特性（定格出力 $1000 \mathrm{~A}, 50 \mathrm{~V}$, 無負荷電圧 $90 \mathrm{~V}$ ) の電源を 3 台並列に接続して使用し，さらに同一の電源 を磁界発生用として 1 台使用した。鋼管は互いに䋓縁さ
1 D.C Welders for arc
5 Power supply shoe
2 D.C Source for mangetic
6 Handle for clamping excitition
7 Cylinder
3 Specimen
8 Oil pressure unit
4 Exciting coil
9 Control unit

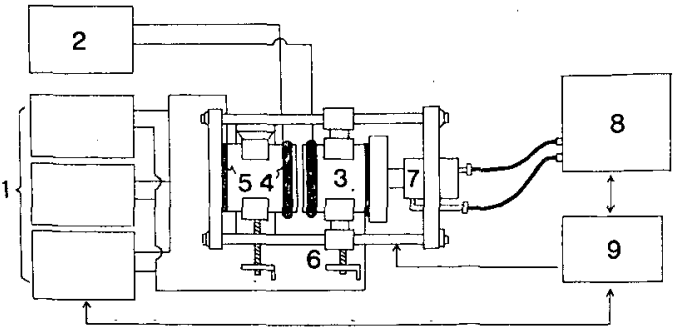

Fig. 1 Experimental equipment 